\title{
A reflection on language and identity in Indonesia
}

Edition 7, 2021

Dr Justin Wejak

DOI: $10.37839 / M A R 2652-550 X 7.9$

I grew up in a linguistically homogenic village on the small island of Lembata in the Lesser Sunda region of Indonesia. Everyone in the village speaks the same mother tongue, known as Baolangu dialect. This dialect is a local variation of Lamaholot, an Austronesian language spoken in the eastern part of Flores island and the neighbouring islands including my home island of Lembata, Adonara, Solor, Alor and Pantar. The Lamaholot language was also known previously during the colonial era as Solorese. The term Lamaholot partly corresponds with the island name Solor, or Holot, situated between the islands of Flores, Adonara, and Lembata.

During my childhood, the local dialect spoken in the village community of Baolangu was comprised of mainly localised words, compared to the dialect version spoken today which is more a mixture of words from the local dialect and Indonesian, or more precisely Melayu Nagi, also known as Melayu Larantuka. Larantuka is the name of the main town in the eastern part of the island of Flores. The evolution of language or dialect poses a critical question on how it affects people's sense of identity and the constructed notion of ethnic or racial purity. Do people's perceptions concerning their ethnic identities and purity change along with the change of speech?

I have been told by some people in the village that I sound different, perhaps in terms of accent, when speaking my mother tongue, even though I speak it relatively fluently. I was told, "saya sudah jadi orang luar" (I have become an outsider) simply because, to them, I sound different when speaking the same mother tongue as they 
do. The construction of the insider versus outsider is worth exploring, particularly how people feel when they are expected to speak in certain ways in social interactions.

Even though I grew up in a monolinguistic village, the children in the village and surrounding villages were exposed to multilingualism from early childhood, given that there are numerous dialects and languages spoken in the Regency of Lembata, which has a total population today of over 135,000. In neighbouring villages different dialects are spoken, so when visiting each other villagers are always expected to be aware of their language differences so misunderstanding can be anticipated and personal offence can be avoided.

For the locals, 'salah bahasa' (literally, 'wrong language') in verbal communication can cause discomfort and conflict in peoples' relationships. Language mistakes that cause offence can only be amended through a reconciliation ritual, often accompanied by 'sangsi adat' (traditional sanction) in the form of goods such as a traditional sarong as appropriate and agreed upon. This is necessary to restore one's good name that has been polluted as the result of the 'salah bahasa'.

The notion 'salah bahasa' refers to people using the wrong words or calling someone older or of a higher social status by their names without the use of an appropriate term of respect such as 'bapak' or 'Pak' (literally, father, or for a male person who is older or of a higher social status), and 'ibu' or 'Bu' (literally, mother, or for a female person who is older or of a higher social status). 'Salah bahasa' can also refer to how one speaks, which can be noticed in intonation, rather than the actual words.

Indeed, knowing who one is in relation to others is crucial for knowing how to communicate with expected politeness according to the local adat (customary law). Language and politeness are inseparable in communication, and some societies such as Indonesia emphasise politeness in speech more than others. The knowledge of one's identity and others in relation to kinship is important in determining what register of language is to be used in conversation. There are many details and 
aspects one needs to know for effective communication and particularly to ascertain that the person who is older or of higher status socially is paid due respect in oral communication. For example, kinship terms in my local language tell me who I am in relationship to other people. The translation of these terms into Indonesian or English does not always provide the nuances of the relationship. This is just one example of how language is an important part of our social identity.

\section{Multilingualism is experienced at the market, not at school}

Back when I was a child, at the market in the coastal town of Lewoleba, people interacted with one another using their own dialects combined with the local variation of Indonesian, or local Malay. In the short time spent at the market one would learn new words and expressions from other local dialects. I used to enjoy going to the market because I found it amusing listening to people loudly speaking different languages and dialects with distinctive sounds and accents. Market, not school, was the first place where I felt exposed to linguistic otherness. Back then, when we heard people talking, we were quickly able to identify their place of origin and ethnicity. This skill of identification is important to learn as a child, and it was learnt naturally and in an unstructured way through interactions at the market or elsewhere on dirt paths to and from the market.

In primary school, not in kindergarten because back then there was no kindergarten, pupils began to learn Indonesian by reading children's book such as Ini Budi (This Is Budi). Given the limited access to books, the same book was usually read numerous times in class, not at home, throughout the year. During school time, Indonesian was spoken very little at least in class; outside the classroom in the school yard all pupils spoke their mother tongue, and more so at home.

When attending junior secondary school-equivalent to grades 7-9 in Australia-in the town away from the village but still on the same island, we had to learn to speak 
more Indonesian with our school mates and teachers, as most of them were from other villages. Then for high school-that is grades 10-12-and for tertiary study, I had to move to Flores, where Indonesian was the main language of communication. During that time, due to interactions with students from other places, I became proficient in another local dialect and spoke it rather fluently, and remain confident speaking it, but gladly without losing my mother tongue of Baolangu, which is very important to me.

As widely known, most children in Indonesian villages grew up learning Indonesian as a second language; it is a language of reading and writing, and a language of education; not a language of every day communication. In my case, I only started to become confident speaking it once I was in high school in Flores. Looking back to my formative years as a child and young teenager what first constructed my shared ethnic identity with the Indigenous community of Baolangu was the local dialect, not the national language of Indonesian. Indonesian language was foreign to me then and to others in the village. Back then when trying to speak Indonesian most children felt like being thrown out of their linguistic comfort zone; they felt as though some aspects of their identity was re-negotiated.

A I recall, children who tried to speak Indonesian were often laughed at and teased by others. I think, this was not only because it sounded 'funny', but because there was a perception then that to be a part of local community one must always speak the local dialect with members of the community. This is considered necessary for acceptance and for a sense of belonging. Perhaps, because of this, often villagers today are amazed and happy to hear the locals who have for years left the community for study or work still speaking the local dialect with fluency. This highlights the correlation between language and identity particularly the role of mother tongue in the construction of indigeneity and shared identity. 


\section{Language as an indicator of identity}

Speaking the local dialect variation not only defines one's Indigenous identity shared with the community, but more so re-affirms one's acceptance and belonging. Furthermore it is necessary for the continuation of social structures and relationships in the society. A sense of Indigenous identity, as in the case of Baolangu, is shown through the ability to speak the language not just for everyday communication, but also for understanding ritual language and symbolism.

When customary marriage rituals are performed in the community of Baolangu, for instance, the language used is the local language or dialect, which sounds more poetic than the everyday language. This is because the villagers believe that the poetic language used in rituals has magical and mythical power in ascertaining acceptance by the ancestral spirits. The problem today is that many in the village no longer know the full poetic language used in rituals which means that some of the fundamental aspects of the shared Indigenous identity as cultured people are gradually eroding. Language erosion means cultural erosion, and the people's shared identity closely attached to the language and culture may need to be reconstructed.

As noted earlier, through verbal interactions people would often be able to know each other's identity, including where they come from geographically, and which ethnic entity they are part of. It is certainly not an exaggeration to say that language defines one's identity, but at the same time particularly ethnic identity also determines what language one should be learning or speaking. On several occasions when travelling in Indonesia, I have been admired by other Indonesians whom I happen to meet for my fluency in speaking Indonesian.

Such admiration always surprises me. It makes me wonder why they thought that I am not Indonesian, and therefore not expected to speak Indonesian, let alone speak it fluently. Interestingly, when they found out that I am Indonesian, they became a little embarrassed and said sorry, to which I sometimes jokingly reply that I could 
take them to court for slander of my origins. Sometimes jokes can be a positive way to help relax people in tense situations, such as when making mistakes, intentionally or unintentionally. In general, Indonesians like to joke, and their language(s), maybe like other languages, allow them to do so creatively and effectively.

This experience and perception of language and identity as something shared within and amongst the community is common throughout Indonesia. Being multilingual is natural to most Indonesians, to communicate with other Indonesians and even people around the world due to global interactions. Globalisation of languages seems to have become a norm nowadays. That means that people around the world could become closer to each other as they are re-constructing a new form of identity that transcends their local and national boundaries. Language is indeed powerful; it has the power to unite, but also to divide; to include and to exclude.

As a national language, Indonesian has proven to be constructive in unifying the whole nation-state, first as the language of struggle (bahasa perjuangan) against colonialism in the political sense since it was first declared in 1928, then as the language of independence (bahasa kemerdekaan) and language of revolution since the Declaration of Independence in 1945. During Suharto's era, Indonesian became the symbol of development (pembangunan) and modernity. There was a strong government campaign about the importance of Indonesian as the national language. During the era of Suharto's New Order, even more emphasis was placed on the importance of Indonesian as the ideological national language that needed to be mastered by all Indonesians.

There was a perception back then that to be considered educated, advanced and modern one needed to be Indonesian literate. This language literacy expectation is understandable given that the Indonesian language is used in almost all public contexts, including education, commerce, media and entertainment. Indonesian language remains one of the key indicators of the so-called national identity that has proved to be effective in unifying a nation of many islands, languages and ethnicities. Most Indonesians are bilingual. They speak their mother tongue as well as 
Indonesian. For Indonesians living in diaspora their Indonesian language and identity is a powerful connecting factor. In Indonesia they might feel foreign to each other, but outside Indonesia language connects them, and they share an identity.

This emphasis on the importance of the national language, however, comes with a cost. Today many local languages throughout the archipelago are endangered, and that can mean that the richness of local identities are shifted. The phenomena of language endangerment in multilingual Indonesia needs to be tackled at all levels and spheres. Local schools and universities should be encouraged to and subsidised for teaching local languages aimed at increasing interest in, and awareness of, the importance of preserving local languages as a way to maintain multilingualism and multiculturalism in plural Indonesia. Language maintenance-of national and local languages-is therefore imperative, not a choice.

There are over 700 living languages spoken in Indonesia, which means that it has about 10 percent of the world's languages, making it the second most linguistically diverse nation in the world after Papua New Guinea. There is a saying that language is the mirror of culture, meaning that language is fundamental to the construction of cultural identity. Language is one of the most tangible aspects of any given culture. For this reason, Indonesia's multilinguistic identity is to be celebrated rather than being feared as a threat to nationalism. This sense of threat was implied in Indonesia's former vice president Jusuf Kalla's assertion that: "Kita membutuhkan bahasa persatuan yang lebih cepat untuk berkomunikasi sehingga tidak perlu ditangisi bila bahasa-bahasa daerah semakin berkurang" (We need a unitary language that is faster to communicate so that there is no need to cry when regional languages are decreasing).

Language is dynamic and so too is identity; they are not static and fixed, remaining the same for all times. Nor are they primordial things that must be preserved. Moreover, identity can be complex and fluid, it is not just about one's identification of oneself, but it is also how one is identified in relation to otherness based upon important elements such as language, beliefs and religion, class and ideology, where 
one lives and studies, and occupation. In this writing I have recounted some stories of my encounters with different languages and my reflections on those stories that illustrate the interconnectedness between language and identity as dynamic entities.

Main image: A market in Larantuka, Flores. Credit: Jacques Beaulieu/Flickr. This image was cropped. 